\title{
A Rare Neoplasm of the Testis: Capillary Hemangioma
}

\section{Testisin Nadir bir Neoplazmı: Kapiller Hemanjiyom}

\author{
Sevdegül MUNGAN', Havvanur TURGUTALP', Şafak ERSÖZ1', Ferda KESKIN'1, Ömer KUTLU²
}

Department of ${ }^{1}$ Pathology and ${ }^{2}$ Urology, Karadeniz Technical University, Faculty of Medicine, TRABZON, TURKEY

\begin{abstract}
Intratesticular vascular neoplasms are extremely rare tumors and mostly seen in children or young adults. We reported a case of capillary hemangioma of the testis to attract attention to testicular hemangioma and also to prevent invasive surgery of the testis.

The patient was an 18-year-old boy with a testicular mass. Scrotal sonography revealed a varicocele in the left testis and a simple cyst in the left epididymis. There was a solid hypoechoic neoplastic area 75 $\mathrm{mm}$ in diameter in the right testis. The laboratory findings including tumor markers and serum levels of $\alpha$-fetoprotein and ß-human chorionic gonadotrophin were normal. The patient underwent right orchiectomy and the pathology diagnosis was capillary hemangioma.

Testicular neoplasms derived from connective tissue, blood vessels and musculature are uncommon and intratesticular tumors of vascular origin are extremely rare. There are only 21 cases reported in the literature. The pathologists and the surgeon have to be aware of this entity as the prognosis of the neoplasm determines the method of surgery. Capillary hemangioma of the testis can be similar to malignant testicular tumors on clinical presentation, as well as on ultrasonography and magnetic resonance imaging. Although it is impossible to differentiate a hemangioma from a seminoma before the operation, intraoperative frozen study may be helpful in the differential diagnosis. Frozen section must be performed if the neoplasm has significant vascular proliferation identified by Doppler sonography. Because of the benign nature of this lesion, conservative surgical treatment by means of tumor enucleation with preservation of the testis is possible if intraoperative frozen section examination can be performed.
\end{abstract}

Key Words: Testicular neoplasm, Hemangioma, Vascular neoplasms

\begin{abstract}
ÖZ
İntratestiküler vasküler neoplazmlar oldukça nadir tümörlerdir ve en sık çocuklar ve genç erişkinlerde saptanırlar. Biz bir testiküler kapiller hemanjiyom olgusunu testis hemanjiyomları üzerine ilgi çekerek, testisin invaziv cerrahisini önlemek amaciyla literatüre sunduk.

18 yaşında testiküler kitlesi olan erkek hastada, skrotal ultrason ile sağ testiste varikosel ve sağ epididimde $6 \mathrm{~mm}$ çaplı basit kist tespit edilmiştir. Ayrıca sol testiste $75 \mathrm{~mm}$ çaplı solid, hipoekoik alan mevcuttur. Laboratuvar bulguları; tümör markerları ve serum $\alpha$ fetoprotein, ß-human koryonik gonadotropin seviyeleri normaldir. Hastaya sol orşiyektomi yapılmış ve patolojik tanısı kapiller hemanjiyom olarak rapor edilmiştir.

Testisin bağ doku, damar ve kas dokularından köken alan neoplazmları oldukça nadirdir. Ancak damar kökenli intratestiküler tümörleri çok daha nadirdir. Literatürde sunulmuş sadece 21 olgu bulunmaktadır. Neoplazmın prognozu operasyonda belirleyici bir faktör olduğu için bu nadir antite gerek cerrah gerekse patolog tarafından akılda tutulması gereken bir durumdur. Testisin kapiller hemanjiyomu klinik ve radyolojik olarak (ultrasonografik ve manyetik rezonans görüntüleme) malign tümörlerine benzer. Operasyon öncesinde hemanjiyom ile seminom ayırımının radyolojik olarak yapılması mümkün olmamasına karşın operasyon sırasında yapılacak frozen çalışma ile ayırıcı tanı yapılabilir. Doppler ultrason ile tümörün belirgin vasküler proliferasyonu saptanır ise frozen çalışma yapılmalıdır. $\mathrm{Bu}$ tümörün benign yapısından dolayı intraoperatif frozen çalışma yapıldığı takdirde tümör enükleasyonu ile testisi korumak mümkün olacaktır.
\end{abstract}

Anahtar Sözcükler: Testiküler neoplazmlar, Hemanjiyom, Vasküler neoplazmlar

\section{INTRODUCTION}

Hemangiomas are exceedingly rare in the testis. Only 21 testicular hemangioma cases have been reported in the English literature as indexed in PubMed. Most cases are in the pediatric population. Hemangiomas have a similar sonographic and magnetic resonance imaging appearance with malignant tumors of the testis, especially seminoma.

Received : 20.11.2009

Accepted : 26.04 .2010
Although it is impossible to differentiate a hemangioma from a seminoma before the operation, intraoperative frozen study may be helpful in differential diagnosis. Radical orchiectomy is the standard procedure for solid testicular tumors but enucleation is considered adequate therapy for hemangiomas. Most cases in literature underwent radical orchiectomy, as in our current case. It is possible to diagnose this rare neoplasm by intraoperative frozen study.

Correspondence: Sevdegül MUNGAN

Department of Pathology, Karadeniz Technical University, Faculty of Medicine, TRABZON, TURKEY

E-mail: sevdegulaydin@yahoo.com Phone: +90 4623775409 


\section{CASE REPORT}

An 18-year-old male presented with testicular pain. There was no history of trauma. A small palpable mass was identified on right testis by physical examination. The left testis could not be examined because of pain. Scrotal sonography revealed a varicocele in the left testis and a 6-mm simple cyst in the left epididymis. There was a solid, roundish, demarcated hypoechoic area $75 \mathrm{~mm}$ in diameter in the right testis. Colour Doppler sonography showed increased blood flow within the lesion. The lesion was located in the upper pole of the right testis. The laboratory findings including tumor markers, particularly the serum levels of $\alpha$-fetoprotein and $\beta$-human chorionic gonadotrophin were normal. The patient underwent right orchiectomy.

On pathology examination there was a well-circumscribed nodule $7 \mathrm{~mm}$ in diameter located in the parenchyma of the upper pole in the right orchiectomy specimen and $1 \mathrm{~mm}$ distant to the tunica albuginea but not involving the testicular hilum or epididymis. The cross-section of the mass was seen to be blue / reddish. Microscopically, paraffin-embedded sections verified the diagnosis of a capillary hemangioma, showing characteristic features of a vascular tumor with proliferation of capillary-sized vascular spaces. The spaces contained red blood cells and were lined by spindle shaped endothelial cells without anaplastic features (Figure 1A,B). The tumor nodule expanded into the interstitium within the seminiferous tubules. Spermatogenesis was present with spermatids in the surrounding seminiferous tubules. Mitotic figures and pleomorphism were not seen in neoplastic cells. The neoplastic cells were positive with CD34, Factor VIII, and Vimentin immunohistochemically (Figure 2A,B,C). There was no immunohistochemical reaction with inhibin, AFP and PLAP in the neoplastic cells.

\section{DISCUSSION}

Testicular capillary hemangioma is an exceptionally rare neoplasm in adults (1). In the pediatric population, $60 \%$ of the hemangiomas are located in the head and neck, $25 \%$ in the trunk and $15 \%$ in the extremities (2). There are 21 reported testicular hemangioma cases in the literature $(3,4)$, and only 4 adult patient were reported in a review of the English literature $(1,5)$. These patients are young men aged between 18 and 45 years. Suriawinata et al. reported 20 testicular hemangiomas, most of them under 18 years old, and 6 cases occurred in adults aged 25-73 years (4).

Four histological types of testicular hemangiomas are reported (1). Eight testicular vascular neoplasms were classified as cavernous hemangiomas, and eight cases classified as histiocytoid (6-8). One case was reported as papillary endothelial hyperplasia (9), and five cases except ours were diagnosed as capillary hemangiomas $(1,5)$. Our case is a capillary type hemangioma.

Although it was reported that testicular hemangiomas commonly present with a palpable mass and pain is a inconsistent feature $(1,3,4,8)$, our patient had pain in left testis. A right testicular mass was identified by scrotal sonography. Serum tumor markers ( $\alpha$-fetoprotein and $\beta$-HCG ) were within normal limits $(1,4,8)$.
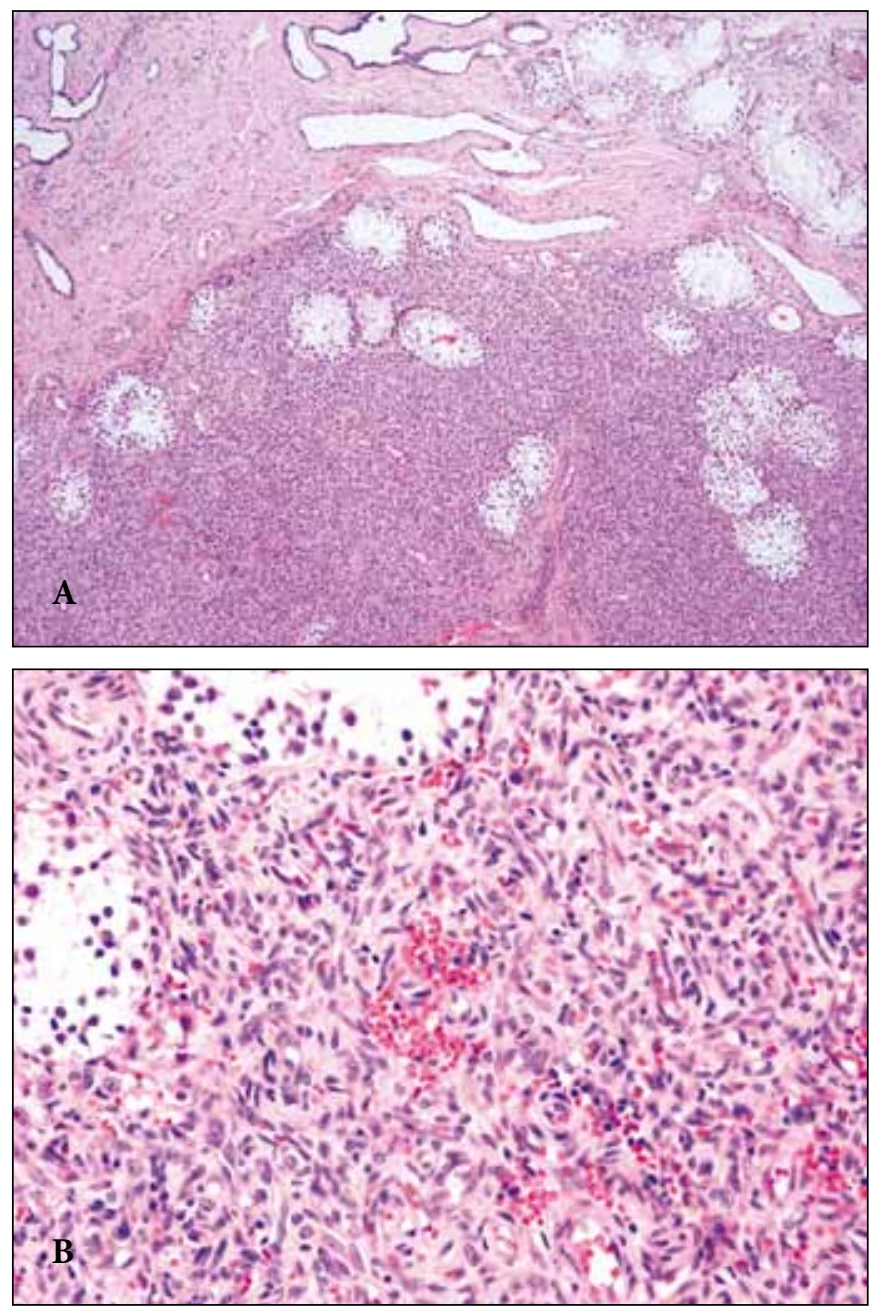

Figure 1: A) Vascular benign neoplasm in testis parenchyma. The neoplastic border and the adjacent pubertal seminiferous tubules can be seen (H\&E; x100). B) The tumor, composed of abundant vascular spaces and proliferation of capillary-sized vessels. Capillary vessels containing erythrocytes. Vascular spaces lined by spindle-shaped endothelial cells without any anaplastic feature (H\&E; x200). 

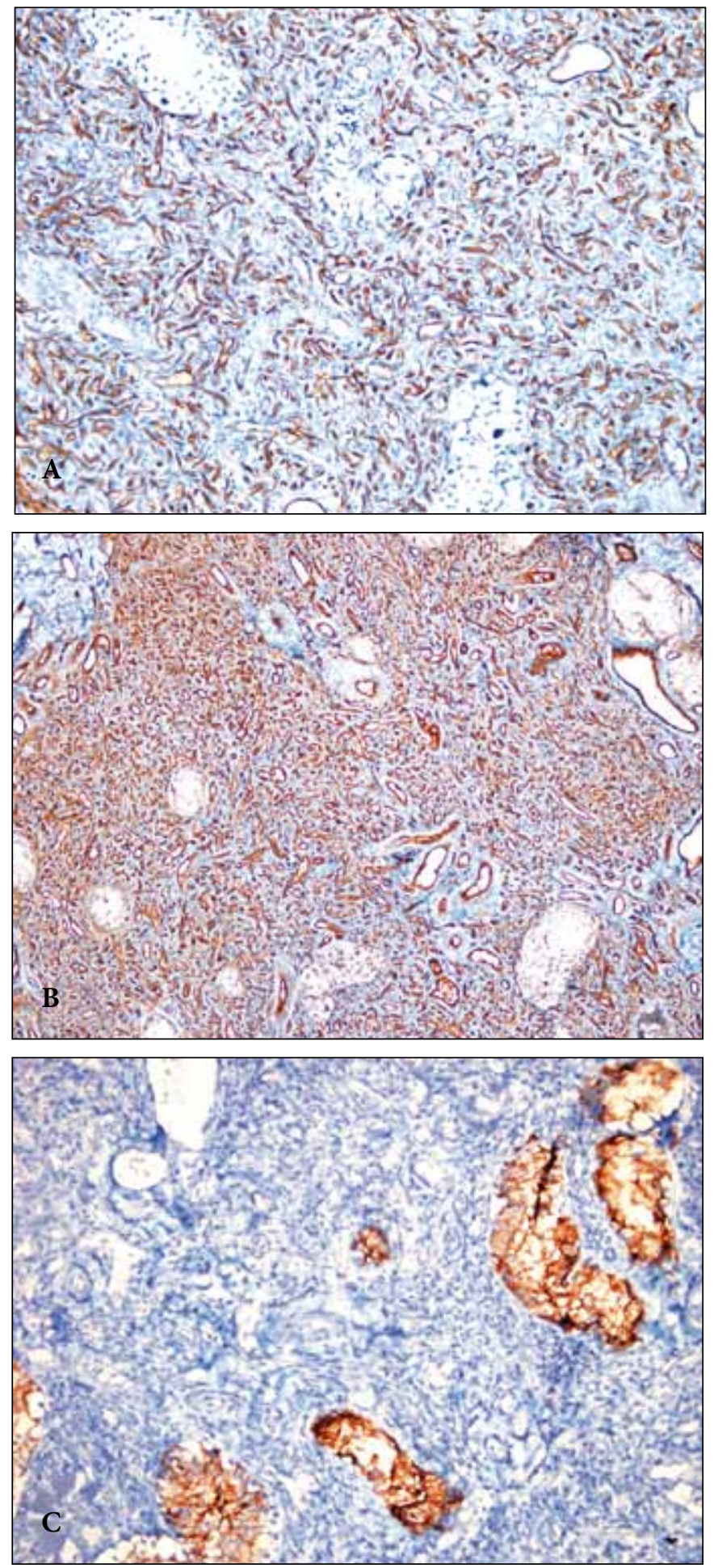

Figure 2: Neoplastic endothelial cells showing prominent expression of the vascular markers CD34 and Factor VIII. Seminiferous tubules show no immunohistochemical reaction with CD34 and Factor VIII. (A: CD34 x100, B: Factor VIII x100) $\mathrm{C}$ : Inhibin is negative in the neoplastic endothelial cells but it is positive in benign seminiferous tubules (x200).
The microscopic appearance of capillary hemangioma on hematoxylin-eosin stain is characteristic. Frozen sections from small biopsies, more solid tumors, and the type of histiocytoid and epitheloid hemangiomas may cause confusion about diagnosis and classification $(7,10)$. Rosai and co-workers have used the vascular neoplasm concept for all histological types of hemangiomas (11).

The differential diagnosis must include germ cell tumors (seminoma, teratoma), adenomatoid tumor, and sex-cord stromal tumors such as Sertoli cell tumor. The presence of proliferative capillary-sized vascular spaces containing red blood cells are the most important microscopic evidence for differential diagnosis of capillary hemangioma. Nuclear pleomorphism and mitotic activity are absent, and the cells lining vascular spaces are positive for $\mathrm{CD} 34$, and negative for inhibin. Immunohistochemical studies may be helpful in the differential diagnosis. Any positivity for placental alkaline phosphatase, inhibin, cytokeratins, CD117 or calretinin would suggest an alternate diagnosis (3).

We report a case of testicular capillary hemangioma and emphasize the importance of intraoperative examination of this tumor. Frozen section must be performed if the neoplasm has significant vascular proliferation identified by Doppler sonography. To date, all reported vascular testicular tumors have demonstrated benign behaviour, with no evidence of local recurrence or metastasis (1). However, capillary hemangioma can be very similar to malignant testicular tumors on clinical presentation and also by sonography and magnetic resonance imaging (5). Because of the benign nature of this neoplasm, preservation of the testis is possible if the diagnosis can be performed during the operation by frozen sections.

\section{REFERENCES}

1. Mazal PR, Kratzik C, Kain R, Susani M: Capillary hemangioma of the testis. J Clin Pathol 2000, 53: 641 -642

2. Ermis B, Otken A, Zulfikar B, Yilmaz K, Ilter M, Sogut A: Hemangiomas. Turkiye Klinikleri J Med Sci 1996, 16: 423-426

3. Talmon GA, Stanley SM, Lager DJ: Capillary hemangioma of the testis. Int J Surg Pathol 2009, 20 (Epub ahead of print ).

4. Suriawinata A, Talerman A, Vapnek JM, Unger P: Hemangioma of the testis: Case reports of unusual occurences of cavernous hemangioma in fetus and capillary hemangioma in an older man. Ann Diagn Pathol 2001, 5: 80-83

5. Essig M, Knopp MV, Hawighorst H, van Kaick G: MRI of capillary hemangioma of the testis. J Comput Asist Tomogr 1997, 21: $402-404$

6. Morehead RP, Thomas WC: Cavernous hemangioma of the testicle. J Urol 1944, 51: 72 -74 
7. Banks ER, Mills SE: Histiocytoid (epithelioid) hemangioma of the testis. The so-called vascular variant of adenomatoid tumor. Am J Surg Pathol 1990, 14: 584 -589

8. Mazzella FM, Sieber SC, Lopez V: Histocytoid hemangioma of the testis: a case report. J Urol 1995, 153: 743 -744

9. Cricco CF Jr, Buck AS: Hemangioendothelioma of the testis: second reported case. J Urol 1980, 123: 131 -132

10. Allen PW, Ramakrishna B, MacCormac LB: The histiocytoid hemangiomas and other controversies. Pathol Ann 1992, 2: 51-87

11. Rosai J, Gold J, Landy R: The histocytoid hemangioma. A unifying concept embracing several previously described entities of the skin, soft tisssue, large vessels bone and heart. Hum Pathol 1979, 10: $707-730$ 